\title{
Measuring innovative performance: is there an advantage in using multiple indicators?
}

Citation for published version (APA):

Hagedoorn, J., \& Cloodt, M. M. A. H. (2003). Measuring innovative performance: is there an advantage in using multiple indicators? Research Policy, 32, 1365-1379. https://doi.org/10.1016/S0048-7333(02)001373

Document status and date:

Published: 01/01/2003

DOI:

10.1016/S0048-7333(02)00137-3

Document Version:

Publisher's PDF, also known as Version of record

\section{Please check the document version of this publication:}

- A submitted manuscript is the version of the article upon submission and before peer-review. There can be important differences between the submitted version and the official published version of record.

People interested in the research are advised to contact the author for the final version of the publication, or visit the DOI to the publisher's website.

- The final author version and the galley proof are versions of the publication after peer review.

- The final published version features the final layout of the paper including the volume, issue and page numbers.

Link to publication

\footnotetext{
General rights rights.

- You may freely distribute the URL identifying the publication in the public portal. please follow below link for the End User Agreement:

www.umlib.nl/taverne-license

Take down policy

If you believe that this document breaches copyright please contact us at:

repository@maastrichtuniversity.nl

providing details and we will investigate your claim.
}

Copyright and moral rights for the publications made accessible in the public portal are retained by the authors and/or other copyright owners and it is a condition of accessing publications that users recognise and abide by the legal requirements associated with these

- Users may download and print one copy of any publication from the public portal for the purpose of private study or research.

- You may not further distribute the material or use it for any profit-making activity or commercial gain

If the publication is distributed under the terms of Article $25 \mathrm{fa}$ of the Dutch Copyright Act, indicated by the "Taverne" license above, 


\title{
Measuring innovative performance: is there an advantage in using multiple indicators?
}

\author{
John Hagedoorn*, Myriam Cloodt \\ MERIT, Faculty of Economics and Business Administration, University of Maastricht, P.O. Box 616, \\ 6200 MD Maastricht, The Netherlands
}

Received 29 May 2002; received in revised form 21 October 2002; accepted 23 October 2002

\begin{abstract}
The innovative performance of companies has been studied quite extensively and for a long period of time. However, the results of many studies have not yet led to a generally accepted indicator of innovative performance or a common set of indicators. So far the variety in terms of constructs, measurements, samples, industries and countries has been substantial. This paper studies the innovative performance of a large international sample of nearly 1200 companies in four high-tech industries, using a variety of indicators. These indicators range from R\&D inputs, patent counts and patent citations to new product announcements. The study establishes that a composite construct based on these four indicators clearly catches a latent variable 'innovative performance'. However, our findings also suggest that the statistical overlap between these indicators is that strong that future research might also consider using any of these indicators to measure the innovative performance of companies in high-tech industries.
\end{abstract}

(C) 2002 Elsevier Science B.V. All rights reserved.

Keywords: High-tech industries; Innovative performance; Patents

\section{Introduction}

The management and applied economics literature on innovation and related topics has a long history of struggling with the measurement of the innovative performance of companies. Both generally available measures such as R\&D inputs, patent counts, patent citations, or counts of new product announcements, and more specific survey-based measurements of this particular performance by companies have been used in trying to capture this innovative performance

\footnotetext{
* Corresponding author. Tel.: +31-43-3883823; fax: +31-43-3884893.

E-mail addresses: j.hagedoorn@mw.unimaas.nl (J. Hagedoorn), m.cloodt@mw.unimaas.nl (M. Cloodt).
}

of companies. ${ }^{1}$ Many studies use a single indicator (R\&D, patents, patent citations, or new product announcements) arguing that the specific indicator that is applied has fewer shortcomings than the other indicators. Some studies use two or more indicators to generate one construct. Given the variety in constructs, measurements, samples, databases, industries and country settings and inconsistency in definitions,

\footnotetext{
${ }^{1}$ In the following, we will mainly consider these generally available innovation measures found in the public domain or in large databases and not those obtained from survey-research. Bibliometric indicators could also be used for measuring research output in terms of the yield of scientific papers. However, there are some serious methodological problems in relating classifications of fields of scientific output to technology and industry classifications. Moreover, this paper focuses on the measurement of innovative performance and not on scientific performance.
} 
it is of no surprise that there appears to be hardly any clear understanding of the concept and measurement of innovative performance.

The main purpose of this paper is to establish a better understanding of the innovative performance of companies, considering the possible use of both a number of single indicators or various combinations of multiple indicators in a composite measure of performance. This exercise implies that we attempt to measure 'the' quality of performance by means of a latent variable and that we analyse the usefulness of multiple indicators, constructing a composite measure of the innovative performance of companies (see also Lanjouw and Schankerman, 1999). The advantage of such a multi-indicator approach is that, instead of assuming the 'correctness' of a single indicator, probably taken for reasons of convenience, an analysis of multiple indicators might allow us to measure innovative performance through a more complex, more informative, composite measure. In addition to this, a composite measure can be analysed in detail, in terms of the individual indicators and with reference to the contribution of each indicator to the latent variable 'innovative performance'. This particular approach enables us to measure the information gains from using particular indicators. This latter aspect of the analysis also indicates that our research does not imply that a multiple-indicator approach is by definition superior. In case of strong statistical association between indicators, each indicator could replace any other measure used in the analysis.

Given the purpose of this paper, it should be clear that this paper is methodological in nature as it presents an analysis of the measurement of innovative performance. It does not outline a theory or a model analysing and explaining differences in the innovative performance of companies. In that sense, the following analysis is self-referential, i.e. innovative performance is exclusively defined in terms of individual measures or the common factor linking the different indicators used in the analysis. The main objective of this paper, therefore, is to better understand the possible advantages of specific single indicators or of composite measures, using multiple indicators related to latent variables, that conditional on the observed characteristics of these indicators, might generate greater insight.

In the following, we will first discuss a number of concepts that are relevant in the context of measur- ing innovative performance and that also enable us to picture the possible relationships between the different indicators of this performance. The next section presents an overview of the literature on indicators such as R\&D input, patent counts, patent citations and new product announcements. In that context it turns out that R\&D inputs could be a reasonable indicator of innovative effort, patents could be a more than acceptable indicator of innovative output, patent citations could be used to measure the quality of innovative output and new product announcements could indicate the level of product innovation. We will also discuss the possible statistical relationship between these indicators as found in a number of studies. Based on our understanding of previous research, we will formulate three research questions. This is followed by a description of the large international sample of companies in four high-tech sectors and a description of the specific variables that we will analyse. We also offer a brief explanation of the rationale behind the choice of industries. The four high-tech studies for which we will investigate the appropriate measures of innovative performance are aerospace and defense, computer and office machinery, pharmaceuticals and electronics and communications. The empirical analysis of the different indicators of innovative performance, based on factor analysis, will be presented in the next section. This is followed by a discussion of the results and the conclusions that can be drawn from this study.

\section{The relationship between inventive, technological and innovative performance}

Concepts such as invention, technology and innovation and the related performance of companies have to be clearly defined in order to improve our comprehension of some technical issues related to the measurement of innovation. Therefore, we will briefly outline our understanding of each of these concepts.

We define inventive performance as the achievements of companies in terms of ideas, sketches, models of new devices, products, processes and systems (Ernst, 2001; Freeman and Soete, 1997). As discussed further below, inventive performance is frequently measured in the context of patents where both raw counts of patents and patent citations are taken as the actual measures. Following Griliches (1998), 


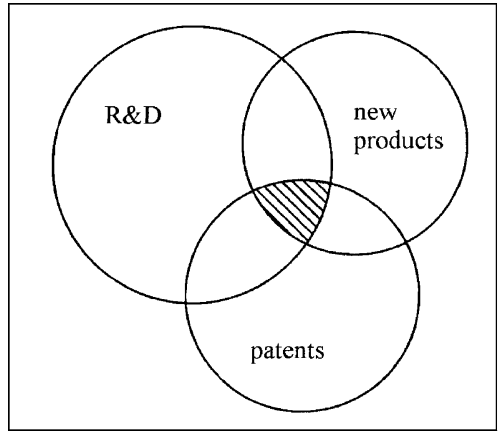

(A)

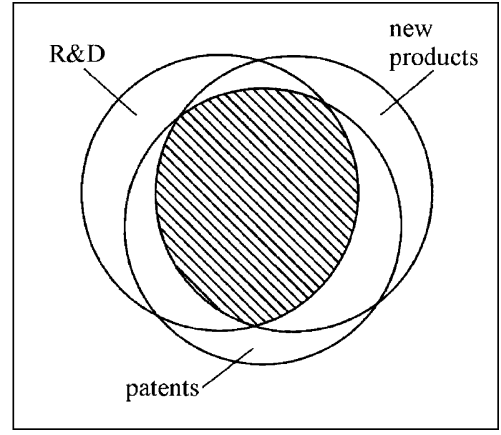

(B)

Fig. 1. Venn diagrams representing the relationship between $R \& D$, patents and new products in two hypothetical industries or two industry-average companies (A and B) with different degrees of overlap (see also Basberg, 1987).

technological performance can be defined as the accomplishment of companies with regard to the combination of their R\&D input, as an indicator of their research capabilities, and their $R \& D$ output in terms of patents. We can also differentiate between innovative performance in the narrow and in the broad sense. Innovative performance in the narrow sense refers to results for companies in terms of the degree to which they actually introduce inventions into the market, i.e. their rate of introduction of new products, new process systems or new devices (Freeman and Soete, 1997). In that case new product announcements can be applied as an indicator of innovative performance.

A broader understanding of innovative performance encompasses the three previous measures of performance as it indicates the achievement in the trajectory from conception of an idea up to the introduction of an invention into the market (Ernst, 2001). This broad innovative performance therefore overarches the measurement of all stages from $R \& D$ to patenting and new product introduction. In other words, this definition of innovative performance in the broad sense focuses on both the technical aspects of innovation and the introduction of new products into the market, but it excludes the possible economic success of innovations as such (see also Acs and Audretsch, 1989; Ahuja and Katila, 2001; Archibugi, 1992; Ernst, 2001; Freeman and Soete, 1997; Grupp, 1994; Lanjouw and Schankerman, 1999; Stuart, 2000; Trajtenberg, 1990).

Our understanding of the different measures, which might interact in the innovative performance of companies, can be explained further using Venn diagrams.
These Venn diagrams picture the possible overlap between R\&D, patents (both counts and citations) and new product announcements as indicators of innovative performance, see Fig. 1. It is well known that the overlap between $R \& D$, patents and new products is not necessarily complete. Full (100\%) overlap is usually not expected because not all patents are directly related to $R \& D$ and the same applies to new products of which only a part of the total number are protected by patents. Also, the space in the squares that surround the Venn diagrams can represent non-measurable technological change or technological change not accounted for by these measures.

The actual intersection between $\mathrm{R} \& \mathrm{D}$, patents and new products in the Venn diagrams depend on the specific nature of the industry. We submit that the degree of overlap between $\mathrm{R} \& \mathrm{D}$, patents and new product announcements determines the usefulness of single or multiple indicators. The more an industry or its average company is characterized by a high $R \& D$ intensity, high patenting intensity and a high ratio for new product introduction, the larger the intersection in the Venn diagram. In case the overlap is complete or almost complete, i.e. in case of (nearly) complete association of measures, the assessment of innovative performance can probably be limited to one of the overlapping indicators (see Fig. 1B). In case the overlap is very small, one has to clearly differentiate between inventive performance, technological performance and innovative performance in the narrow sense (see Fig. 1A). In other cases with varying degrees of overlap between $R \& D$, patents and new products, the 
use of multiple indicators might provide a better understanding of the actual innovative performance of companies.

\section{Indicators of innovative performance}

As discussed briefly in the above, we can analyse technological performance, inventive performance, and innovative performance in the narrow sense in terms of $\mathrm{R} \& \mathrm{D}$ inputs, patent counts, patent citations, and new product announcements. These indicators can be used individually or combined in a multi-dimensional setting to measure innovative performance in the broader sense.

The current literature on the measurement of innovation points towards some interesting perspectives on using these different indicators. In the following, we will present a brief overview of this literature that will be helpful in providing some background to our research questions.

\section{1. $R \& D$ inputs}

The literature usually takes $R \& D$ expenditures primarily as an input indicator of the efforts that companies make in establishing R\&D that might eventually lead to output. However, apart from the actual correlation of $R \& D$ input with $R \& D$ output through patents (Griliches, 1990, 1998; Hausman et al., 1984; Hitt et al., 1997), R\&D efforts can also indicate the innovative competences of companies that are found to affect the performance of companies, particularly in high-tech industries (Duysters and Hagedoorn, 2001; Henderson and Cockburn, 1994). In that context, $R \& D$ inputs of companies are part of the broader routines that companies follow in their innovative efforts, where previous $R \& D$ expenditures affect subsequent R\&D inputs (Nelson and Winter, 1982). Successful R\&D input at a previous stage will increase the commitment to the allocation of future $R \& D$ resources. In other words, within the routines that most companies have developed in managing their R\&D inputs, the actual R\&D efforts not only reflect current input but also their previous successes that are an integral part of the skills that companies develop in creating an R\&D strategy with a stable set of long-term projects (Hagedoorn, 1989). We expect that, particularly in high-tech industries, $R \& D$ inputs are as much affecting future output as they are part of the current technological performance of a company in terms of generating new ideas, new blue prints and new models, part of which will eventually lead to new patents and new products (Griliches, 1998; Baysinger and Hoskisson, 1989; Hall, 1990).

\subsection{Patents}

As most of the other indicators, the patent measure, in particular the use of raw patent counts, is subject to a longstanding debate regarding its bias and shortcomings (Archibugi, 1992; Cohen and Levin, 1989; Dosi, 1988; Griliches, 1998). International and sectoral differences in patenting behaviour, differences in patenting between large companies and smaller firms, the identical weight given to some very important patents as well as to run-of-the-mill patents, the fact that patents only cover a part of the overall trajectory from $R \& D$ to innovation, all of these 'shortcomings' feature in the literature that discusses the use of patents.

However, it appears that, certainly in large parts of the economics literature, raw patent counts are generally accepted as one of the most appropriate indicators that enable researchers to compare the inventive or innovative performance of companies in terms of new technologies, new processes and new products (Acs and Audretsch, 1989; Aspden, 1983; Bresman et al., 1999; Cantwell and Hodson, 1991; Freeman and Soete, 1997; Griliches, 1998; Napolitano and Sirilli, 1990; Patel and Pavitt, 1995; Pavitt, 1988). Even authors who are somewhat critical of the overall use of patents as a performance indicator, such as Arundel and Kabla (1998) and Mansfield (1986), admit that patents can be an appropriate indicator in the context of many high-tech sectors. These literatures also suggest that the less patents are used for broad cross-sectional analysis that ignores inter-sectoral differences in the propensity to patent, the better patents reflect the performance of companies in one or a few sectors (see also Ernst, 2001).

\subsection{Patent citations}

Increasingly researchers are using patent citations as an indicator of inventive performance of companies. 
Compared to raw counts of patents, which generate a purely quantitative measure, patent citations also include a measure of the quality of patents. The basic assumption in using this indicator is that there is a positive relationship between the importance of a patent and the degree to which a patent is cited in later patents. This information on previous patents can be traced in each patent application as it is required that each patent cites earlier patents with somewhat similar or related technical claims, also known as the relevant prior art. The number of patent citations for a particular patent indicates its importance or impact.

Patent specialists are somewhat sceptical about the counting of patent citations without the necessary in-depth knowledge necessary to interpret the underlying citation reports that accompany each patent (Michel and Bettels, 2001). However, quantitative analysis of large numbers of patents and patent citations is frequently used in economics (for instance Harhoff et al., 1999; Jaffe et al., 1993; Trajtenberg, 1990) and the management literature (for instance Rosenkopf and Nerkar, 2001; Stuart, 2000).

Evidence of the validity of patent citations as an indicator of the quality of inventions or innovations, in terms of the correlation between the inter-subjective assessment of the importance of patents by technical specialists and the number of citations, is found in a number of studies (Albert et al., 1991; Carpenter et al., 1981; Karki, 1997; Narin et al., 1987; Pavitt, 1988).

\subsection{New product announcements}

Some contributions use new product announcements, traced through various sources and databases, as an indicator of the innovative performance of companies. In their study on 250 US companies, Hitt et al. (1996) apply the degree to which new product announcements of companies were found in Dialog's NPA/plus database as a part of a combined indicator of the innovativeness of companies. Devinney (1993) shows that the positive relationship between the number of patents and new product announcements is primarily found at the level of industries and not at the level of individual companies, where less than $3 \%$ of the variance in individual firm new product announcements is explained by patent intensity.

One of the main problems with using new product announcements, as for instance found in various databases, is that these announcements are based on the press releases of the marketing departments of companies and little or no screening appears to be undertaken by the database operators themselves. In other words, new product announcements by companies themselves are simply accepted as long as companies identify them as such. Patents, on the other hand, in particular those registered in an advanced economy such as the USA, are screened for their original contribution both during the pre-application period and during the actual application period by in-company engineers, patent lawyers and by patent office officials. Therefore, more than with some of the other indicators, careful screening of the data might be necessary with new product announcements in order to avoid major problems with the validity of the results.

\subsection{The statistical association of $R \& D$, patents and new product announcement}

As so many studies apply different indicators, it appears interesting to get a better understanding of the likely statistical association between these different indicators. The majority of studies use only one single indicator but a number of studies use multiple indicators or report on the correlation between some of the indicators mentioned in the above. However, the literature reporting more than one indicator appears to present a somewhat diverse picture when it comes to the possible relationship between $R \& D$ inputs, patent counts and citations, and new products.

Seminal studies by Pakes and Griliches (1984) and Bound et al. (1984) find a rather strong relationship between R\&D and the number of patents across firms and industries. Ahuja and Katila's (2001) study of the international chemical industry reports a correlation of nearly 0.9 between R\&D inputs and patent counts. In their analysis of the international computer industry, Hagedoorn and Duysters (2002) mention a correlation of over 0.5 between the R\&D intensity of companies and their patent counts. However, in their study of US companies involved in nearly 200 acquisitions, Hitt et al. (1991) show a low correlation of only about 0.2 between the R\&D intensity of these companies and their patent intensity.

In one of their early small-scale studies, Narin et al. (1987) find that the quality of research inputs of companies is highly correlated with raw patent counts and 
patent citations. Trajtenberg (1990) demonstrates that citation-weighted patent numbers of companies are more closely correlated with their output measures of innovation, whereas unweighted patent counts are more closely related to R\&D expenditures of companies. Stuart (2000) reports a very high correlation of over 0.8 between raw patent counts and patent citations, the actual measure of innovation in a sample of 150 semiconductor firms. However, Rosenkopf and Nerkar (2001), who studied a smaller sample of optical disk manufacturing companies, find a relatively low correlation of about 0.3 between number of patents and patent citation indicators.

In a study of a sample of 250 US companies, Hitt et al. (1996) establish a substantial correlation of 0.5 between the R\&D intensity of companies and their new product intensity, i.e. the number of new product announcements controlled for size of companies. Brouwer and Kleinknecht (1999) indicate some correlation between patenting and sales of innovative products, although this correlation is far from perfect. As already indicated in the above, Devinney (1993) shows that the specific relationship between the patenting of companies and their new product announcements turns out to be quite weak.

\section{Research questions}

It is obvious from the above that the literature generates a rather mixed bag of findings, to say the least. Some studies suggest that, given the rather high correlation between some indicators, any of these correlated measures could be used as a partial or overall indicator of performance. Yet, the lack of any statistical association found for the same indicators in other studies, appears to suggest that the results from studies using any of these particular measures could be indicator-driven. However, the level of intermediate statistical association between a number of measures, as found in yet another set of studies, indicates that one composite construct with various measures could capture a latent variable that expresses the degree of innovative performance in the broader sense. The somewhat unclear nature of the measurement of innovative performance and other performance indicators, as found in large parts of the literature, appears influenced by a lack of systematic research in multi- ple industries, while frequently using only relatively small samples of companies in a domestic context.

Our understanding of the literature, as outlined in the above, suggests a number of research questions. In order to overcome the major shortcomings of previous research, we will investigate these questions empirically in an international, large-scale, multi-sectoral setting. These research questions are:

1. Is there a systematic disparity between different indicators such as R\&D inputs, patent counts, patent citations and new product announcements?

2. Is there a statistical communality between two or more indicators, indicating that a composite construct could capture a latent variable?

3. Is the statistical association between two or more indicators of such a nature that each of these indicators can be applied as a representative indicator of innovative performance?

\section{Research methodology}

\subsection{Sample}

Our large, international sample of companies covers four high-tech industries: aerospace and defense (SIC-codes 372 and 376), computer and office machinery (SIC-code 357), pharmaceuticals (SIC-code 283) and electronics and communications (SIC-code 36). These high-tech sectors are selected because it is known that particularly in these industries R\&D expenditures, patents and new products play a role in indicating important aspects of innovative performance (OECD, 1997). Our sample consists of 1194 companies of which $51.17 \%$ is found in the electronics and communications industry, $23.45 \%$ is in computer and office machinery, $20.44 \%$ is in pharmaceuticals, and $4.94 \%$ belongs to the aerospace and defense sector.

The literature (Brouwer and Kleinknecht, 1999; Devinney, 1993; Ernst, 2001; Griliches, 1998) suggests that sectoral differences can play a role in explaining the various outcomes with respect to different indicators of innovative performance. Therefore, we will present the results of our analysis for the sample of companies as a whole as well as for each of the sub-samples for the different industries. As suggested by Ernst (2001), we also differentiate internationally 
Table 1

Distribution of size classes of companies in the total sample and for industry sub-samples (1998 annual revenues in US\$ millions)

\begin{tabular}{lccccc}
\hline Size classes & Total & $\begin{array}{l}\text { Aerospace and } \\
\text { defense }\end{array}$ & $\begin{array}{l}\text { Computers and } \\
\text { office machinery }\end{array}$ & Pharmaceuticals & $\begin{array}{c}\text { Electronics and } \\
\text { communications }\end{array}$ \\
\hline $0<100(\%)$ & 66.67 & 61.01 & 69.64 & 70.49 & 64.32 \\
$100<1000(\%)$ & 18.59 & 16.94 & 17.14 & 13.94 & 21.28 \\
$>1000(\%)$ & 14.74 & 22.05 & 13.22 & 15.57 & 14.40 \\
Total $(\%)$ & 100 & 100 & 100 & 100 & 100 \\
$N$ & 1194 & 59 & 280 & 244 & 611 \\
\hline
\end{tabular}

between a North American sub-sample (70.02\%) and companies from other countries, mainly in Europe and Asia (29.98\%). Some details regarding the sectoral and international breakdown of this sample are presented in Appendix A.

Our sample is also diverse in terms of the distribution of the size of companies, representing many size-categories of innovating firms (see Table 1). Most of the companies in our sample $(61.39 \%)$ are relatively small with annual revenues of up to a maximum of US\$ 100 millions. A substantial number of companies $(14.74 \%)$ can be characterized as very large with annual revenues of over US\$ 1 billion. Nearly one quarter of the sample $(18.59 \%)$ can be found in an intermediate size-class. Obviously, there are differences between the industry sub-samples but for each sector we do find a diverse picture in terms of the size-categories for companies.

It is well known that there is no 'official' database with a world-wide, industry-level list of all companies from which one can draw a random sample. Our sample is taken from the Securities Data databank on international companies, which provides information on companies in various industries, including those that were selected for this study. We concentrated on manufacturing sectors because some of the indicators more effectively capture aspects of technical innovation rather than of service innovation (Kleinknecht, 1999). Additional information on revenues and $R \& D$ expenditures of companies in this sample was identified through various other datasets such as Amadeus, Compustat, the Fortune 500 list, and Worldscope. Companies entered the sample if the value of at least one of the variables used in the analysis had a value higher than zero. In other words, companies with zero $\mathrm{R} \& \mathrm{D}$, zero patents, zero patent citations and zero new products were excluded.

\subsection{Variables and data sources}

R\&D expenditures of companies are measured annually and standardized by converting the financial data from national currencies to US dollars. Data on R\&D expenditures were obtained through the well-known databases mentioned in the previous section and through additional internet searches.

We utilize the yearly number of all patents granted to each company as a second indicator. The data on patents are taken from the US Patent and Trademark Office (USPTO) database. We use US patent data for both US and non-US firms. Although these US data could imply a bias in favour of US companies against non-US firms, it is mentioned in the literature that given the importance of the US market, the 'real' patent protection offered by US authorities, and the level of technological sophistication of the US market, it is often compulsory for non-US companies to file patents in the USA (Patel and Pavitt, 1991). Furthermore, to maintain a certain level of consistency, reliability and comparability it is necessary to choose one patenting system instead of several patenting systems across nations (Ahuja and Katila, 2001). ${ }^{2}$

Patent citations for each firm are counted as the yearly patent citations of their patents in all patent classes. Data on patent citations are also taken from the USPTO database.

New products or new product announcements are counted annually for each company in sectors such as aerospace and defense, computers, office equipment, pharmaceuticals, semiconductors and telecom,

\footnotetext{
${ }^{2}$ With hindsight it turned out that there is little indication of major differences between North American (largely US) and non-North American companies, see the correlation for patents and other measures in Appendix B.
} 
as found in the RDS Business \& Industry databank owned by the Gale Group. This database contains the full text of press releases from all industries covering announcements related to products, with a focus on new products and services. In addition to product descriptions, the press releases generally contain key details about new products and technologies, including technical specifications, availability, uses, licensing agreements, distribution channels, and prices. The database covers more than 1500 technical and non-technical journals and can be found on http://www.gale.com. For this study, we separated announcements of product development projects and new services from new product introduction and only use the latter information in the analysis.

For annual R\&D expenditures and yearly patent counts data are obtained for the period 1992-1999, annual patent citations are registered for the years 1992-1998, and yearly new product announcements are counted for the period 1997-2000. We measured the performance of companies in the sample as a whole and for each sub-sample on each indicator with alternating time periods. The first period covers the years 1997 and 1998 for all indicators without any time lags between various indicators. All indicators in the data set share the years 1997 and 1998. The second time period (1995-1999) has an average lag of 1 year between indicators and the third time period (1992-1999) has an average lag of 2 years between indicators. The fourth period is based on different time lags as mentioned in the literature (Cincera, 1997; Hall et al., 1986, 2000; Kondo, 1999; Napolitano and Sirilli, 1990; Pakes, 1985; Pakes and Griliches, 1984; Scherer, 1984a,b). For this period, we took lags of 3 years between R\&D and patents granted, 2 years between patents granted and patent citations, and 1 year between patent citations and new products.

\section{Results}

Our research questions suggest that we are basically making an attempt to understand innovative performance in terms of the possible causal structure among a number of indicators (variables), considering a set of common underlying dimensions or factors. Therefore, factor analysis is applied to examine our research questions. The results of this analysis will only be reported
Table 2

Means and standard deviations for the sample as a whole and sub-samples

\begin{tabular}{|c|c|c|}
\hline Variables & Mean & Standard deviation \\
\hline \multicolumn{3}{|l|}{ Total } \\
\hline R\&D expenditures & 216016.4 & 619104.549 \\
\hline Patent counts & 46.702 & 181.554 \\
\hline Patent citations & 231.519 & 1007.653 \\
\hline New products & 13.399 & 49.276 \\
\hline \multicolumn{3}{|l|}{ Aerospace and defense } \\
\hline $\mathrm{R} \& \mathrm{D}$ expenditures & 178162.8 & 417559.314 \\
\hline Patent counts & 11.063 & 28.36 \\
\hline Patent citations & 44.688 & 111.589 \\
\hline New products & 2.125 & 4.839 \\
\hline \multicolumn{3}{|c|}{ Computers and office machinery } \\
\hline $\mathrm{R} \& \mathrm{D}$ expenditures & 195251.1 & 606422.472 \\
\hline Patent counts & 63.847 & 251.625 \\
\hline Patent citations & 343.435 & 1482.674 \\
\hline New products & 24.528 & 76.719 \\
\hline \multicolumn{3}{|l|}{ Pharmaceuticals } \\
\hline $\mathrm{R} \& \mathrm{D}$ expenditures & 291918.6 & 560573.466 \\
\hline Patent counts & 25.187 & 54.803 \\
\hline Patent citations & 74.869 & 177.736 \\
\hline New products & 7.657 & 14.792 \\
\hline \multicolumn{3}{|c|}{ Electronics and communications } \\
\hline $\mathrm{R} \& \mathrm{D}$ expenditures & 198493.6 & 662087.785 \\
\hline Patent counts & 51.255 & 186.088 \\
\hline Patent citations & 263.267 & 989.636 \\
\hline New products & 11.942 & 44.501 \\
\hline
\end{tabular}

Note: R\&D expenditures are in thousands of US\$.

for the overall sample and its sub-samples for the period 1997-1998. The results for the analyses with different time lags turned out to be almost identical with no significant differences. Some descriptive data on the means and standard deviations for the overall sample and sub-samples are presented in Table 2. Some additional descriptive data on the relationship between indicators for the overall sample and the sub-samples are given in Appendix F. These data suggest that there are inter-sectoral differences between the ratios for the different indicators. In that sense, despite the fact that all four sectors are high-tech industries, there are differences with regard to the degree to which, for instance particular levels of R\&D lead to patents and new products. This phenomenon stresses the importance of understanding inter-sectoral differences, it does not question the use of this particular group of indicators. In order to discover the usefulness of these 
Table 3

Correlations

\begin{tabular}{llllll}
\hline Variables & Total & $\begin{array}{l}\text { Aerospace and } \\
\text { defense }\end{array}$ & $\begin{array}{l}\text { Computers and } \\
\text { office machinery }\end{array}$ & Pharmaceuticals & $\begin{array}{l}\text { Electronics and } \\
\text { communications }\end{array}$ \\
\hline Patents and patent citations & 0.941 & 0.805 & 0.973 & 0.777 & 0.925 \\
Patents and R\&D expenditures & 0.783 & 0.874 & 0.931 & 0.704 & 0.812 \\
Patents and new products & 0.798 & 0.475 & 0.793 & 0.589 & 0.830 \\
Patent citations and R\&D expenditures & 0.709 & 0.856 & 0.891 & 0.704 & 0.748 \\
Patent citations and new products & 0.808 & 0.741 & 0.789 & 0.382 & 0.851 \\
R\&D expenditures and new products & 0.734 & 0.666 & 0.907 & 0.817 & 0.763
\end{tabular}

different indicators, we will first have to consider the outcomes of the factor analysis, presented below.

Obviously a factor model can only be appropriate if variables are to some extent related to each other. ${ }^{3}$ If correlations between variables are lower than 0.30 , it is unlikely that they share common factors. In our sample and sub-samples correlations are greater than 0.30 , suggesting that a factor analysis is appropriate (see Table 3). Similar correlations are found for the sub-samples for North American companies and other companies (see Appendix B). An exception is found for the aerospace and defense industry in non-North American countries. The irregular pattern of correlations, found for this industry and these countries, is probably caused by the relatively small number of 21 companies. $^{4}$

A somewhat more advanced method of determining the appropriateness of factor analysis is the KaiserMeyer-Olkin (KMO) measure. The KMO measure is an index for comparing the magnitudes of the observed correlation coefficients to the magnitudes of the partial

\footnotetext{
${ }^{3}$ Some of the variables (i.e. patent counts and patent citations) could be too strongly dependent on each other if a large number of companies have only zero patents which, ignoring time, will by definition lead to zero patent citations. This will have an upward effect on the correlations. However, within a given period of time (e.g. 1997-1998) or even in each of the other lagged periods, patent citations do not necessarily refer to the patent counts from the same or lagged periods. Furthermore, $47.65 \%$ of the companies in the sample do not have patents whereas $38.11 \%$ of the companies have no patent citations. Or to put it differently, $36.38 \%$ of the companies in this sample that do not have patents in any of these periods, still have patent citations.

${ }^{4}$ As noted in the literature (Hair et al., 1995) factor analytical methods are not well suited in case of a small sample and a low ratio of observations to variables. Even seemingly meaningful results, obtained from such samples, should be interpreted cautiously.
}

correlation coefficients (Norusis, 1993). Higher values for this measure indicate the degree of appropriateness of using factor analysis. In addition to this we can also calculate a measure of sampling adequacy (MSA) for each individual variable. Again, values for this measure indicate whether factor analysis is appropriate or not. For our sample, both the KMO and the MSA measures indicate that factor analysis is an appropriate method to test if $R \& D$ expenditures, patent counts, patent citation counts, and new products share one or more common factors (see Appendix C). This implies that we can continue with the second stage of the statistical analysis, i.e. exploratory factor analysis by means of principal component analysis (Hair et al., 1995).

The results of the initial unrotated factor analysis are very straightforward as the analysis generates only one factor. Given this one-factor solution there is no further need for rotation of factors. The results of the initial unrotated factor analysis are presented in Tables 4 and 5 and Appendices D and E. Table 4, labelled communality measures, is an indication of the strength of the linear association among variables. Squaring the correlation coefficient shows the amount of the variable's total variance accounted for by the factor (Norusis, 1993). Small squared multiple correlation coefficients suggest that the variable should be eliminated from the analysis.

Over $75 \%$ of the communalities are greater than 0.80 , suggesting that $80 \%$ or more of the variable's total variance is accounted for by the factor. In general there are not many differences between the communalities calculated for the sample as a whole and the industry sub-samples (see Table 4). The relatively largest differences involve the variables R\&D expenditures and new products. The variable R\&D expenditures has somewhat lower communalities for the sample as a whole, for the pharmaceutical industry and 
Table 4

Communality measures

\begin{tabular}{llllll}
\hline Variables & Total & $\begin{array}{l}\text { Aerospace and } \\
\text { defense }\end{array}$ & $\begin{array}{l}\text { Computers and } \\
\text { office machinery }\end{array}$ & Pharmaceuticals & $\begin{array}{l}\text { Electronics and } \\
\text { communications }\end{array}$ \\
\hline R\&D expenditures & 0.761 & 0.906 & 0.955 & 0.802 & 0.791 \\
Patent counts & 0.920 & 0.787 & 0.941 & 0.819 & 0.921 \\
Patent citations & 0.888 & 0.905 & 0.918 & 0.600 & 0.900 \\
New products & 0.822 & 0.627 & 0.831 & 0.676 & 0.856 \\
\hline
\end{tabular}

Table 5

Results of the initial unrotated factor analysis for component 1

\begin{tabular}{lccccc}
\hline Variables & Total & $\begin{array}{l}\text { Aerospace and } \\
\text { defense }\end{array}$ & $\begin{array}{l}\text { Computers and } \\
\text { office machinery }\end{array}$ & Pharmaceuticals & $\begin{array}{c}\text { Electronics and } \\
\text { communications }\end{array}$ \\
\hline R\&D expenditures & 0.872 & 0.952 & 0.977 & 0.896 & 0.889 \\
Patent counts & 0.959 & 0.887 & 0.970 & 0.905 & 0.960 \\
Patent citations & 0.943 & 0.951 & 0.958 & 0.774 & 0.949 \\
New products & 0.907 & 0.792 & 0.912 & 0.822 & 0.925 \\
Total Eigenvalue & 3.391 & 3.224 & 3.644 & 2.897 & 3.467 \\
\% variance explained & 84.77 & 80.60 & 91.10 & 72.43 & 86.69 \\
\hline
\end{tabular}

for the electronics and communications industry. The variable new products has lower communalities for the aerospace and defense industry and for the pharmaceuticals industry. An interesting finding is that, compared with the other industries, the communalities for the pharmaceutical industry show relatively low values. As indicated by Appendix D the results for companies from North America and for those from other countries are not significantly different.

Table 5 and Appendix E present the results of the factor analysis. Each row in the table and the appendix contains a factor loading indicating the correlation of that specific variable and the factor. High loadings make the variable representative of the factor. The signs of the factor loadings are all positive and the factor loadings are all statistically significant. $90 \%$ of the factor loadings are above 0.80 , while the lowest factor loading is still 0.774 , indicating that each of the four variables is representative of the factor. Not surprisingly, the factor loadings exhibit the same overall pattern as the communalities with respect to the sample as a whole, the sample with North American companies, and the sample consisting of companies from other countries. Furthermore, the factor loadings reveal the same pattern as the communalities for the variables patent citations and new products in the pharmaceutical industry and for the variable new products in the aerospace and defense industry.

Table 5 and Appendix E also give the total variance explained by each factor. For the sample as a whole nearly $85 \%$ of the total variance is explained by one component, that we label as innovative performance in the broad sense based on its appropriateness for representing the underlying dimension of this particular factor. In the computer and office machinery sector more than $90 \%$ of the total variance is explained by this component. The pharmaceutical industry has the lowest percentage explained by the component, namely $73.23 \%$. The difference of $19.5 \%$ between the average of both the computer and office machinery sector and the pharmaceutical industry is mainly based on the lower factor loadings for patent citations and new products in the pharmaceutical industry. Results for companies from North America and from other countries are almost identical (see Appendix E).

\section{Discussion and conclusions}

Our study covers a large sample of nearly 1200 companies found in four high-tech industries. About 
$70 \%$ of these companies are registered in the USA and Canada, most of the others are from Europe, Japan, South Korea and some south east Asian newly industrialized countries.

Our findings regarding the different indicators of innovative performance in this sample are rather unambiguous, leaving very little space for 'subtle' re-interpretations of the pros and cons of the individual indicators. Also, using different time lags or no time lag at all does not affect the outcome of the analysis. Hence, we can present a set of clear-cut conclusions regarding the possible advantage of multiple indicators for measuring innovative performance in high-tech industries.

First, our research suggests that there is no major systematic disparity amongst R\&D inputs, patent counts, patent citations and new product announcements (research question 1). A systematic disparity was found for neither the sample as a whole, nor for individual sectors, or when taking the international distribution into account.

Second, the statistical communality of the four indicators of innovative performance is high for the sample as a whole and for all but one sub-sample (aerospace and defense outside North America). This indicates that a composite construct based on these indicators catches a latent variable 'innovative performance' that measures the performance of companies in high-tech industries (research question 2). The latent variable innovative performance measures the overall, broad interpretation of innovative performance of companies in terms of their research input, the size of their inventive activities, the quality of their inventive output and their level of new product introduction (see also Mohnen and Dagenais, 2002; Mairesse and Mohnen, 2002).

Third, the results of the analysis, however, also indicate that the overlap between each of these four indicators is that great (similar to Fig. 1B) that in high-tech sectors any of these four indicators could be taken as a measure of innovative performance in the broad sense (research question 3). Certainly in the electronics industry at large, with sub-sectors such as computers, office machinery and electronics and communications, and also in the aerospace and defense sector, each indicator appears to capture the innovative performance of companies. Although the results of our statistical analysis certainly do not dictate that a single indicator approach is invalid for the pharmaceutical industry, a composite construct that overarches all stages of the innovation process could be used for the measurement of innovative performance of companies in this particular sector. The factor loadings in the analysis of this sector specify a slightly higher degree of multidimensionality where R\&D inputs and patent counts represent somewhat different aspects of innovative performance than patent citations and new products (see also Trajtenberg, 1990).

Finally, our findings do not imply that there is no need for additional, context-informed analyses. Future research could consider a number of topics relevant for understanding the measurement of innovative performance. An obvious item for further research is to investigate the usefulness of the current indicators in other industries than these high-tech sectors. We expect that in a number of industries with little $R \& D$, indicators based on patents and new products could still be used although the actual distribution for these measures might be different. As part of the continuous effort to build better theories and improved models to understand innovative performance, it is appealing to focus on the effect that the strategic behaviour of companies has on their innovative performance, explaining how this might influence the different measurements of innovative performance. Also, the inclusion of other indicators might be useful for analysing high-tech industries, although it appears as if the current line-up of measures is quite exhaustive. Furthermore, it should be clear that the measurement of innovative performance in non-manufacturing sectors is in need of a rather different set of indicators. Obviously, future research should consider some alternative measures of innovation that are more appropriate in the context of a wide range of service industries.

\section{Acknowledgements}

The authors would like to thank participants at the ECIS seminar at Eindhoven University of Technology, Anthony Arundel, Pierre Mohnen and two anonymous referees for their suggestions and comments on an earlier version of this paper. 
Appendix A. Distribution of companies in the sample, numbers and \% distribution for sectors and regions

\begin{tabular}{lllll}
\hline Industry & North America & Others & \multicolumn{2}{l}{ Total } \\
\hline Aerospace and defense & $38 ; 4.55 \%, 64.41 \%$ & $21 ; 5.87 \%, 35.59 \%$ & $59 ; 4.94 \%, 100 \%$ \\
Computers and office machinery & $227 ; 27.15 \%, 81.07 \%$ & $53 ; 14.81 \%, 18.93 \%$ & $280 ; 23.45 \%, 100 \%$ \\
Pharmaceuticals & $152 ; 18.18 \%, 62.30 \%$ & $92 ; 25.70 \%, 37.70 \%$ & $244 ; 20.44 \%, 100 \%$ \\
Electronics and communications & $419 ; 50.12 \%, 68.58 \%$ & $192 ; 53.62 \%, 31.42 \%$ & $611 ; 51.17 \%, 100 \%$ \\
Total & $836 ; 100 \%, 70.02 \%$ & $358 ; 100 \%, 29.98 \%$ & $1194 ; 100 \%, 100 \%$ \\
\hline
\end{tabular}

Appendix B. Correlations

\begin{tabular}{|c|c|c|c|c|c|}
\hline Variables & Total & $\begin{array}{l}\text { Aerospace } \\
\text { and } \\
\text { defense }^{\text {a }}\end{array}$ & $\begin{array}{l}\text { Computers } \\
\text { and office } \\
\text { machinery }\end{array}$ & Pharmaceuticals & $\begin{array}{l}\text { Electronics and } \\
\text { communications }\end{array}$ \\
\hline \multicolumn{6}{|l|}{ North America } \\
\hline Patents and patent citations & 0.951 & 0.793 & 0.985 & 0.792 & 0.897 \\
\hline Patents and $R \& D$ expenditures & 0.822 & 0.902 & 0.921 & 0.833 & 0.898 \\
\hline Patents and new products & 0.769 & 0.482 & 0.786 & 0.554 & 0.752 \\
\hline $\begin{array}{l}\text { Patent citations and R\&D } \\
\text { expenditures }\end{array}$ & 0.778 & 0.879 & 0.905 & 0.562 & 0.870 \\
\hline Patent citations and new products & 0.782 & 0.770 & 0.777 & 0.386 & 0.811 \\
\hline R\&D expenditures and new products & 0.796 & 0.659 & 0.925 & 0.864 & 0.828 \\
\hline \multicolumn{6}{|l|}{ Others } \\
\hline Patents and patent citations & 0.964 & 0.859 & 0.987 & 0.827 & 0.968 \\
\hline Patents and R\&D expenditures & 0.764 & -0.30 & 0.980 & 0.592 & 0.787 \\
\hline Patents and new products & 0.903 & 0.122 & 0.940 & 0.625 & 0.907 \\
\hline $\begin{array}{l}\text { Patent citations and } \mathrm{R} \& \mathrm{D} \\
\text { expenditures }\end{array}$ & 0.713 & -0.23 & 0.942 & 0.536 & 0.747 \\
\hline Patent citations and new products & 0.882 & 0.154 & 0.938 & 0.394 & 0.889 \\
\hline R\&D expenditures and new products & 0.775 & 0.940 & 0.933 & 0.771 & 0.791 \\
\hline
\end{tabular}

${ }^{a}$ Correlation matrix is not positive definite.

\section{Appendix C. Results for the KMO and the MSA measures}

\begin{tabular}{llllll}
\hline Variables & Total & $\begin{array}{l}\text { Aerospace and } \\
\text { defense }\end{array}$ & $\begin{array}{l}\text { Computers and } \\
\text { office machinery }\end{array}$ & Pharmaceuticals & $\begin{array}{l}\text { Electronics and } \\
\text { communications }\end{array}$ \\
\hline KMO measure & 0.762 & 0.721 & 0.651 & 0.695 & 0.804 \\
MSA measure & & & & & \\
$\quad$ R\&D expenditures & 0.809 & 0.758 & 0.652 & 0.702 & 0.858 \\
Patent counts & 0.703 & 0.666 & 0.613 & 0.705 & 0.754 \\
Patent citations & 0.703 & 0.788 & 0.679 & 0.671 & 0.750 \\
New products & 0.885 & 0.657 & 0.665 & 0.694 & 0.884 \\
\hline
\end{tabular}




\section{Appendix D. Communalities for North America and others}

\begin{tabular}{llllll}
\hline Variables & Total & $\begin{array}{l}\text { Aerospace and } \\
\text { defense }\end{array}$ & $\begin{array}{l}\text { Computers and } \\
\text { office machinery }\end{array}$ & Pharmaceuticals & $\begin{array}{l}\text { Electronics and } \\
\text { communications }\end{array}$ \\
\hline North America & & & & & \\
$\quad$ R\&D expenditures & 0.834 & 0.921 & 0.963 & 0.897 & 0.917 \\
$\quad \begin{array}{l}\text { Patent counts } \\
\text { Patent citations }\end{array}$ & 0.913 & 0.790 & 0.936 & 0.850 & 0.894 \\
$\quad 0.897$ & 0.915 & 0.924 & 0.611 & 0.909 \\
New products & 0.807 & 0.633 & 0.829 & 0.656 & 0.810 \\
Others & & & & & \\
$\quad$ R\&D expenditures & 0.743 & a & 0.963 & 0.729 & 0.771 \\
Patent counts & 0.946 & a & 0.989 & 0.812 & 0.949 \\
Patent citations & 0.910 & a & 0.969 & 0.661 & 0.921 \\
$\quad$ New products & 0.907 & a & 0.940 & 0.675 & 0.909 \\
\hline
\end{tabular}

${ }^{a}$ The correlation and covariance matrix are not positive definite.

\section{Appendix E. Results of the initial unrotated factor analysis}

\begin{tabular}{|c|c|c|c|c|c|}
\hline Variables & Total & $\begin{array}{l}\text { Aerospace and } \\
\text { defense }\end{array}$ & $\begin{array}{l}\text { Computers and } \\
\text { office machinery }\end{array}$ & Pharmaceuticals & $\begin{array}{l}\text { Electronics and } \\
\text { communications }\end{array}$ \\
\hline \multicolumn{6}{|c|}{ North America, component 1} \\
\hline R\&D expenditures & 0.913 & 0.959 & 0.982 & 0.947 & 0.958 \\
\hline Patent counts & 0.956 & 0.889 & 0.968 & 0.922 & 0.945 \\
\hline Patent citations & 0.947 & 0.957 & 0.961 & 0.782 & 0.953 \\
\hline New products & 0.898 & 0.796 & 0.911 & 0.810 & 0.900 \\
\hline Total Eigenvalue & 3.451 & 3.259 & 3.653 & 3.014 & 3.530 \\
\hline$\%$ variance explained & 86.28 & 81.47 & 91.32 & 75.35 & 88.25 \\
\hline \multicolumn{6}{|l|}{ Others, component 1} \\
\hline$R \& D$ expenditures & 0.862 & a & 0.981 & 0.854 & 0.878 \\
\hline Patent counts & 0.973 & a & 0.994 & 0.901 & 0.974 \\
\hline Patent citations & 0.954 & a & 0.984 & 0.813 & 0.960 \\
\hline New products & 0.952 & $\mathrm{a}$ & 0.970 & 0.822 & 0.954 \\
\hline Total Eigenvalue & 3.506 & a & 3.861 & 2.877 & 3.550 \\
\hline$\%$ variance explained & 87.66 & a & 96.51 & 71.92 & 88.75 \\
\hline
\end{tabular}

${ }^{a}$ The correlation and covariance matrix are not positive definite.

Appendix F. Ratios for the different indicators in the sample as a whole and for sub-samples

\begin{tabular}{lllll}
\hline Industry & $\begin{array}{l}\text { Patent counts/R\&D } \\
\text { expenditures }\end{array}$ & $\begin{array}{l}\text { Patent citations/R\&D } \\
\text { expenditures }\end{array}$ & $\begin{array}{l}\text { New products/R\&D } \\
\text { expenditures }\end{array}$ & $\begin{array}{l}\text { New products/patent } \\
\text { counts }\end{array}$ \\
\hline Aerospace and defense & 0.062 & 0.251 & 0.012 & 0.192 \\
Computers and office machinery & 0.327 & 1.759 & 0.126 & 0.385 \\
Pharmaceuticals & 0.086 & 0.257 & 0.026 & 0.304 \\
Electronics and communications & 0.258 & 1.326 & 0.060 & 0.233 \\
Total & 0.216 & 1.072 & 0.062 & 0.287 \\
\hline
\end{tabular}

Note: R\&D expenditures are in millions of US\$. 


\section{References}

Acs, Z.J., Audretsch, D.B., 1989. Patents as a measure of innovative activity. Kyklos 4, 171-180.

Ahuja, G., Katila, R., 2001. Technological acquisition and the innovative performance of acquiring firms: a longitudinal study. Strategic Management Journal 22, 197-220.

Albert, M.B., Avery, D., Narin, F., McAllister, P., 1991. Direct validation of citation counts as indicators of industrially important patents. Research Policy 20, 251-259.

Archibugi, D., 1992. Patenting as an indicator of technological innovation: a review. Science and Public Policy 6, 357-358.

Arundel, A., Kabla, J., 1998. What percentage of innovations are patented? Experimental estimates in European firms. Research Policy 27, 127-142.

Aspden, H., 1983. Patent statistics as a measure of technological vitality. World Patent Information 5, 170-173.

Basberg, B.L., 1987. Patents and the measurement of technological change: a survey of the literature. Research Policy 12, 227-237.

Baysinger, B.D., Hoskisson, R.E., 1989. Diversification strategy and $R \& D$ intensity in multi-product firms. Academy of Management Journal 34, 205-214.

Bound, J., Cummins, C., Griliches, Z., Hall, B.H., Jaffe, A., 1984. Who does R\&D and who patents? In: Griliches, Z. (Ed.), R\&D, Patents, and Productivity. University of Chicago Press, Chicago, pp. 21-54.

Bresman, H., Birkenshaw, J., Nobel, R., 1999. Knowledge transfer in international acquisitions. Journal of International Business Studies 30, 439-462.

Brouwer, E., Kleinknecht, A., 1999. Innovative output, and a firm's propensity to patents: an exploration of CIS micro data. Research Policy 28, 615-624.

Cantwell, J., Hodson, C., 1991. Global R\&D and UK competitiveness. In: Casson, M. (Ed.), Global Research Strategy and International Competitiveness. Blackwell Scientific Publications, Oxford, pp. 133-182.

Carpenter, M.P., Narin, F., Woolf, P., 1981. Citation rates to technologically important patents. World Patent Information 3, $160-163$.

Cincera, M., 1997. Patents, R\&D, and technological spillovers at the firm level: some evidence from econometric count models for panel data. Journal of Applied Econometrics 12, 265-280.

Cohen, W.M., Levin, R.C., 1989. Empirical studies of innovation and market structure. In: Schmalensee, R., Willig, R. (Eds.), Handbook of Industrial Organization, vol. 2. Elsevier, Amsterdam, pp. 1059-1107.

Devinney, T.M., 1993. How well do patents measure new product activity? Economic Letters 41, 447-450.

Dosi, G., 1988. Sources, procedures, and microeconomic effects of innovation. Journal of Economic Literature 26, 1120-1171.

Duysters, G., Hagedoorn, J., 2001. Do company strategies and structures converge in global markets? Evidence from the computer industry. Journal of International Business Studies 32, 347-356.

Ernst, H., 2001. Patent applications and subsequent changes of performance: evidence from time-series cross-section analyses on the firm level. Research Policy 30, 143-157.
Freeman, C., Soete, L., 1997. The Economics of Industrial Innovation. Pinter, London.

Griliches, Z., 1990. Patent statistics as economic indicators: a survey. Journal of Economic Literature 28, 1661-1697.

Griliches, Z., 1998. R\&D and Productivity: The Econometric Evidence. The University of Chicago Press, Chicago.

Grupp, H., 1994. The measurement of technical performance of innovations by technometrics and its impact on established technology indicators. Research Policy 23, 175-193.

Hagedoorn, J., 1989. The Dynamic Analysis of Innovation and Diffusion. Pinter, London.

Hagedoorn, J., Duysters, G., 2002. The effect of mergers and acquisitions on the technological performane of companies in a high-tech environment. Technology Analysis and Strategic Management 13, 67-85.

Hair, J.F., Anderson, R.E., Tatham, R., Black, W., 1995. Multivariate Data Analysis with Readings. Prentice-Hall, Englewood Cliffs, NJ.

Hall, B.H., 1990. The impact of corporate restructuring on industrial research and development. Brookings Papers on Economic Activity 3, 85-135.

Hall, B.H., Griliches, Z., Hausman, J., 1986. Patents and R\&D: Is there a lag? International Economic Review 27, 265-283.

Hall, B.H., Jaffe, A., Trajtenberg, M., 2000. Market Value and Patent Citations: A First Look. NBER Working Series Paper, Working Paper 7741.

Harhoff, D., Narin, F., Scherer, F.M., Vopel, K., 1999. Citation frequency and the value of patented inventions. Review of Economics and Statistics 81, 511-515.

Hausman, J., Hall, B.H., Griliches, Z., 1984. Econometric models for count data with an application to the patents-R\&D relationship. Econometrica 52, 909-938.

Henderson, R., Cockburn, I., 1994. Measuring competence: exploring firm effects in pharmaceutical research. Strategic Management Journal 15, 63-84 (special issue winter).

Hitt, M.A., Hoskisson, R.E., Ireland, R.D., Harrison, J.S., 1991. Effects of acquisitions on R\&D inputs and outputs. Academy of Management Journal 34, 693-706.

Hitt, M.A., Hoskisson, R.E., Johnson, R.A., Moesel, D.D., 1996. The market for corporate control and firm innovation. Academy of Management Journal 39, 1084-1119.

Hitt, M.A., Hoskisson, R.E., Kim, H., 1997. International diversification: effects on innovation and firm performance in product-diversified firms. Academy of Management Journal 40, 767-798.

Jaffe, A., Trajtenberg, M., Henderson, R., 1993. Geographic localization of knowledge spillovers as evidenced by patent citations. Quarterly Journal of Economics 108, 577-598.

Karki, M.M.S., 1997. Patent citation analysis: a policy analysis tool. World Patent Information 19, 269-272.

Kleinknecht, A., 1999. Measuring Product and Service Innovation: An Assessment of Alternative Indicators. Rotterdam Institute for Business Economic Studies, Erasmus Universiteit, Rotterdam, The Netherlands.

Kondo, M., 1999. R\&D dynamics of creating patents in the Japanese industry. Research Policy 28, 587-600. 
Lanjouw, J.O., Schankerman, M., 1999. The Quality of Ideas: Measuring Innovation with Multiple Indicators. NBER Working Paper 7345.

Mairesse, J., Mohnen, P., 2002. Accounting for innovation and measuring innovativeness: an illustrative framework and application. In: Proceedings of the Paper Presented at MERITWorkshop, Maastricht University, 15-16 February 2002.

Mansfield, E., 1986. Patents and innovation: an empirical study. Management Science 32, 173-181.

Michel, J., Bettels, B., 2001. Patent citation analysis: a closer look at the basic input data from patent search reports. Scientometrics 51, 185-201.

Mohnen, P., Dagenais, M., 2002. Towards an innovation intensity index: the case of CIS1 in Denmark and Ireland. In: Kleinknecht, A., Mohnen, P. (Eds.), Firm Performance: Econometric Explorations of Survey Data. Palgrave, New York.

Napolitano, G., Sirilli, G., 1990. The patent system and the exploitation of inventions: results of a statistical survey conducted in Italy. Technovation 10, 5-16.

Narin, F., Noma, E., Perry, R., 1987. Patents as indicators of corporate technological strength. Research Policy 16, 143-155.

Nelson, R., Winter, S., 1982. An Evolutionary Theory of Economic Change. Harvard University Press, Cambridge, MA.

Norusis, M.J., 1993. SPSS ${ }^{\circledR}$ for Windows ${ }^{\text {TM }}$, Professional Statistics $^{\mathrm{TM}}$, Release 6.0. SPSS Inc, Chicago, IL.

OECD, 1997. Revision of High Technology Sector and Product Classification. OECD, Paris.

Pakes, A., 1985. On patents, R\&D, and the stock market rate of return. Journal of Political Economy 93, 390-409.
Pakes, A., Griliches, Z., 1984. Patents and R\&D at the firm level: a first look. In: Griliches, Z. (Ed.), R\&D, patents and productivity. The University of Chicago Press, Chicago, pp. 55-72.

Patel, P., Pavitt, K., 1991. Large firms in the production of the world's technology: an important case of non-globalization. Journal of International Business Studies 22, 1-21.

Patel, P., Pavitt, K., 1995. Divergence in technological development among countries and firms. In: Hagedoorn, J. (Ed.), Technical Change and the World Economy: Convergence and Divergence in Technology Strategies. Edward Elgar, Aldershot, pp. 147-181.

Pavitt, K., 1988. Uses and abuses of patent statistics. In: van Raan, A.F.J. (Ed.), Handbook of Quantitative Studies of Science and Technology. Elsevier, Amsterdam, pp. 509-536.

Rosenkopf, L., Nerkar, A., 2001. Beyond local search: boundaryspanning, exploration, and impact in the optical disk industry. Strategic Management Journal 22, 287-306.

Scherer, F.M., 1984a. Innovation and Growth: Schumpeterian Perspectives. MIT Press, Cambridge.

Scherer, F.M., 1984b. Using linked patent and R\&D data to measure interindustry technology flows. In: Griliches, Z. (Ed.), R\&D, Patents and Productivity. The University of Chicago Press, Chicago, pp. 417-464.

Stuart, T.E., 2000. Interorganizational alliances and the performance of firms: a study of growth and innovation rates in a high-technology industry. Strategic Management Journal 21, 791-811.

Trajtenberg, M., 1990. A penny for your quotes: patent citations and the value of innovations. Rand Journal of Economics 21, 172-187. 